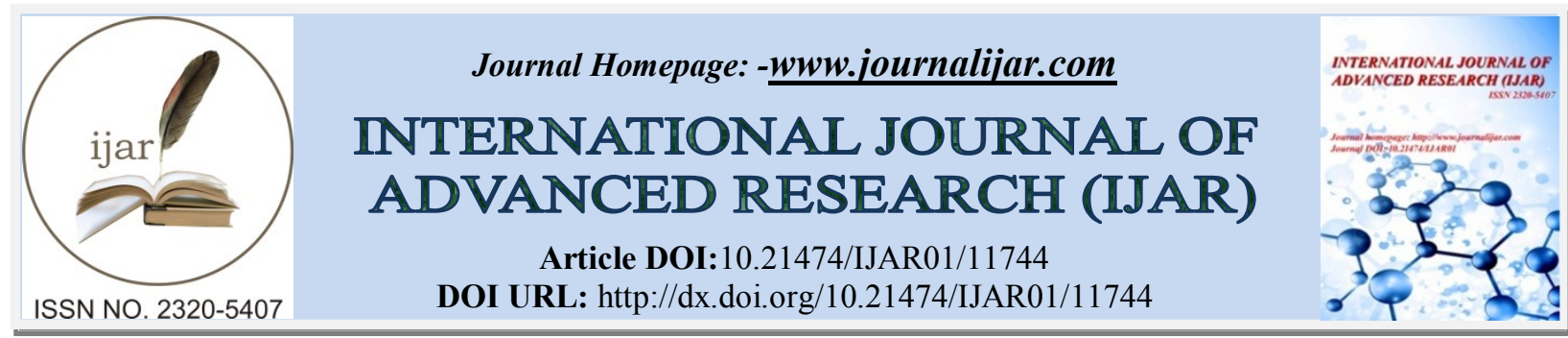

RESEARCH ARTICLE

\title{
ENTRUSTABLE PROFESSIONAL ACTIVITIES (EPAs) FROM CLINICAL TO BASIC SCIENCE DISCIPLINES: A METHODOLOGICAL PROPOSAL
}

\section{Fernández Morilla ${ }^{1}$ and Joao Costa $M^{2}$}

1. Research Grup of Sustainability and Integral Education, Department: Didactic of Experimental Sciences. International University of Catalonia (UIC-Barcelona), Spain.

2. Department of Medical Education, Universidade do Minho, Braga, Portugal.

\section{Manuscript Info}

Manuscript History

Received: 20 July 2020

Final Accepted: 24 August 2020

Published: September 2020

\section{Key words:-}

Competence-Based Education, Entrustable Professional Activities, Basic Science Competencies, Research Skills

\section{Abstract}

Competence-based education has gained in popularity at many countries. Competence is regarded as the possession and development of integrated skills, knowledge, appropriate attitudes, and experience for the successful performance of one's life roles. A new concept is gaining great relevance in the clinic medical education context: Entrustable Professional Activities (EPAs); these activities allow curricular development of competencies, no longer in the classroom. $E A_{S}$ have been identified for many graduate clinical education programmes, but none for basic sciences disciplines. With the idea of transfer EPA concept to the development and assessment of basic science competencies, this work offers: (1) a EPA -competencies matrix to work the competency E2 described by the Association of American Medical College (linked with research skills); (2) the development of a complete EPA model. The proposal opens a line to discuss the implications and challenges that this concept-transfer offers.

Copy Right, IJAR, 2020,. All rights reserved.

\section{Introduction:-}

\section{Competence concept:}

There are various approaches to and definitions of the concept of competence. In terms of approach, there have been three main traditions in competence research since the middle of the last century: the behaviorist, the generic and the cognitive (Norris, 1991; Eraut, 1994; Wesselinket al., 2005).

The behaviorist approach stresses the importance of observing successful and effective job performers and determining what differentiates them from their less successful counterparts (McClelland, 1973). This approach dominated the management strategy literature of the 1990s (Mitrani et al., 1992; Campbell \& Sommers Luchs, 1997; Nadler \& Tushman, 1999). Competences in this respect are acquired through training and development and competence is based on the description of observable behavior or performance in situ (Mulder et al., 2007).

The generic approach is aimed more at identifying the common abilities that explain variations in performance. Competences determined in this way can be applied to different professional groups. Goncziet al. (1995)confirmed the diverse forms that generic competences could take depending on the workplaces context. 
The definition of competence employed in the cognitive approach includes all the mental resources of individuals that are used to master tasks, acquire knowledge and achieve a good performance (Weinert, 2001). It is often used simultaneously with intelligence or intellectual abilities. The classical cognitive approaches focusing on general cognitive competencies include psychometric models of human intelligence, information processing models and the Piagetian model of cognitive development (Mulder et al., 2007)

The three traditions of competence research mentioned above are identified as the most complete, however, there are many attempts to categorize research on competence and define the concept (Mulder et al. 2008). Other examples are the following. The concept of competence used in the PISA comprises cognitive competence (knowledge), functional competence (skills), social competence and self-competence (Achtenhagen, 2005). DeSeCo (OECD Program Definition and Selection of Competencies) defined the key competencies needed in daily life that are common across cultures (OECD/DeSeCo/Rychen, 2003).

Another EU-level example of competence framework construction is the ECTS (European Credit Transfer System in Higher Education). The goal here is to achieve enhanced cooperation in vocational training and harmonization of higher education by the creation of a set of reference levels. These levels should be described in terms of learning outcomes, a typology of 'knowledge, skills and competencies' has been developed (Winterton et al. 2005). Knowledge in this typology is captured as cognitive competence, skills are captured as functional competence, and attitudes and behavior as social competence.

\section{Competency-based education (CBE):}

CBE is not a novel educational model. It emerged towards the end of the $1960 \mathrm{~s}$, influenced by the educational objective taxonomy research of Bloom (Bloom et al., 1956) and the work developed by Mager in 1962 on instructional objectives (in Hardem, 2002). Recently, Competence-based education has gained in popularity and many countries, educational institutions and educational authorities are aiming to install 'competence-based' education (Spencer \& Spencer, 1993; Weinert, 2001; Van Dongen, 2003).A holistic approach of competence-based education is normatively put forward and competence is regarded as the possession and development of integrated skills, knowledge, appropriate attitudes and experience for the successful performance of one's life roles (Taylor, Popham, 1984, 1986, in McNamara, 1992; Korthagen, 2004; Struyven\& De Meyst, 2010). It has been stated that CBE is creating opportunities for students and workers, close to their world of experience in a meaningful learning environment (preferable the professional practice) wherein the learner can develop integrated, performance-oriented capabilities (knowledge structures and also cognitive, interactive, affective and where necessary psychomotor skills, and attitudes and values) for carrying out tasks and solving problems (Wesselink et al., 2003).

\section{EPA concept:}

A new concept is gaining great relevance in the clinic medical education context: Entrustuble Professional Activities (EPAs) (ten Cate et al., 2015; Chen et al., 2015; ten Cate et al., 2020). These activities allow curricular development of competencies, no longer in the classroom, with the application of competence-based education. The development of an EPA allows several competencies to be implemented simultaneously and are designed in such a way that they offer the student or trainee the opportunity to act and make decisions autonomously. The tutor supervises the activity with a higher or lower degree of intervention depending on the case, so that the evaluation is based on observation and collection of evidence through reports or portfolios that fill the learning, providing a feed-back of developed EPA. Therefore, the evaluation is based on what the evaluator "does" and not on what he would "do". EPAshave been identified for many graduate medical education programmes including paediatrics, obstetrics, internal medicine, family medicine and oncology between others (Scheele et al., 2013; Gilhooly et al., 2014; Caverzagie et al., 2015; Shultz et al., 2015; Shumway et al. 2015), also recently EPAs are gaining interest in pharmaceutical practice (McCloskey et al., 2017; Vos Chair et al., 2018; Heines et al., 2018) but none for basic sciences disciplines.

\section{Proposal development:}

As an example of the behavioral approach of the definition on competencies, the Association of American Medical College (AAMC, 2009) recognize Epstein and Hundert (2002) competence definition "the habitual and judicious of communication, knowledge, technical skills, clinical reasoning, emotions, values and reflection of daily practice for the benefit of the individual and the community being served" like most accepted in medical education. As it was stated before this approach consider that competencies are acquired through training, and development competence is based on the description of observable behavior or performance in situ (Mulder et al., 2007). 
Based on this approach and definition of competence, this document mentions the global competencies that students should developed during basic undergraduate training in any itinerary of studies in health or life sciences. Among them, the Competency E2: "Demonstrate understanding of the process of scientific inquiry, and explain how scientific knowledge is discovered and validated", closely linked to the student's research skills (as a part of this competency) was selected as a starting point to develop this proposal. As the AAMC document established this competency is attached to some learning-outcomes: (1) Develop observational and interpretative skills through hands in laboratory or field experiences; (2) Demonstrate ability to measure with precision, accuracy and safety; (3) Be able to operate basic laboratory instrument for scientific measurement; (4) Be able to articulate scientific questions and hypotheses, design experiments, acquire data, perform data analyses and present results; (5) Demonstrate the ability to search effectively, to evaluate critically, and to communicate and analyze the scientific literature. The competency E2 is general, by definition and design, but if learning outcomes are expressed in terms of the level of competence to be obtained by the learner, they can be used like examples of roles or competencies domains to depth in the specificity of the competency, creating a framework with which educators can build educational programs.

The inform of the American Association for the Advancement of Science (AAAS, 2009) mention some examples of authentic research experiences in undergraduate biology, that universities are engaging and what can be considered CBE experiences -according to the definition stated byWesselink et al. (2003)- to specifically work research competencies. Curse-based projects, independent or summer research, community-based student research or laboratory research courses are some these experiences that provide students the opportunity to learn science by doing it (Sadler \&Mckinney, 2010). Few biology departments can accommodate all students in pursuing authentic research projects, but for some of these methodological approaches the goal may not be creation of new knowledge but simply the development of the student as a scientist or the provision of opportunities to experience the process of science. In many cases, students in authentic research experiences can work in teams and contribute to obtain data to research publication. A strategy adopted for many professors is designed the activities around their personal research interests (AAAS, 2009). Related with this, it is very important to consider the role of professors as research mentors (Pfund et al., 2015) or supervisors of the trainees, positive mentoring has been cited as the most important factor in degree attainment (Solorzano, 1998) and also as improve retention students in academia (Ries et al., 2009).

Is in these experiences' context, that EPAs design and development, will gain meaning to cover the gap between theory and practice in basic science competencies and to offer an example of systematization of CBE in this area. So, with the idea of transfer EPA concept to the development and assessment of basic science competencies, this work offers: (1) a EPAs-competencies matrix to work global competency E2; (2) the development of a complete EPA model.

\section{EPAS-Competencies matrix:}

As ten Cate et al. (2015) propose a matrix using seven competencies domains or CanMED roles -developed by Frank (2005)- that are supposed to be integrated in the medical profession, to construct this matrix, we propose five roles/competencies domains (figure 1) linked to Competency E2 (what include research skills) described by the AAMC (2009). These roles are essential in the scientific training of health/life science undergraduate students to become a professional researcher or to build upon new scientific knowledge and critical thinking.

As EPAs can be considered discrete tasks that supervisors entrust a trainee with unsupervised once he has obtained adequate competencies, the matrix was constructed (figure 2) considering two main aspects: (1) the matrix should answer the question: which competencies must an individual possesses before a critical activity can be entrusted to this person to complete unsupervised? (2) matrix must provide an assessment guidance for both trainee and supervisor. 


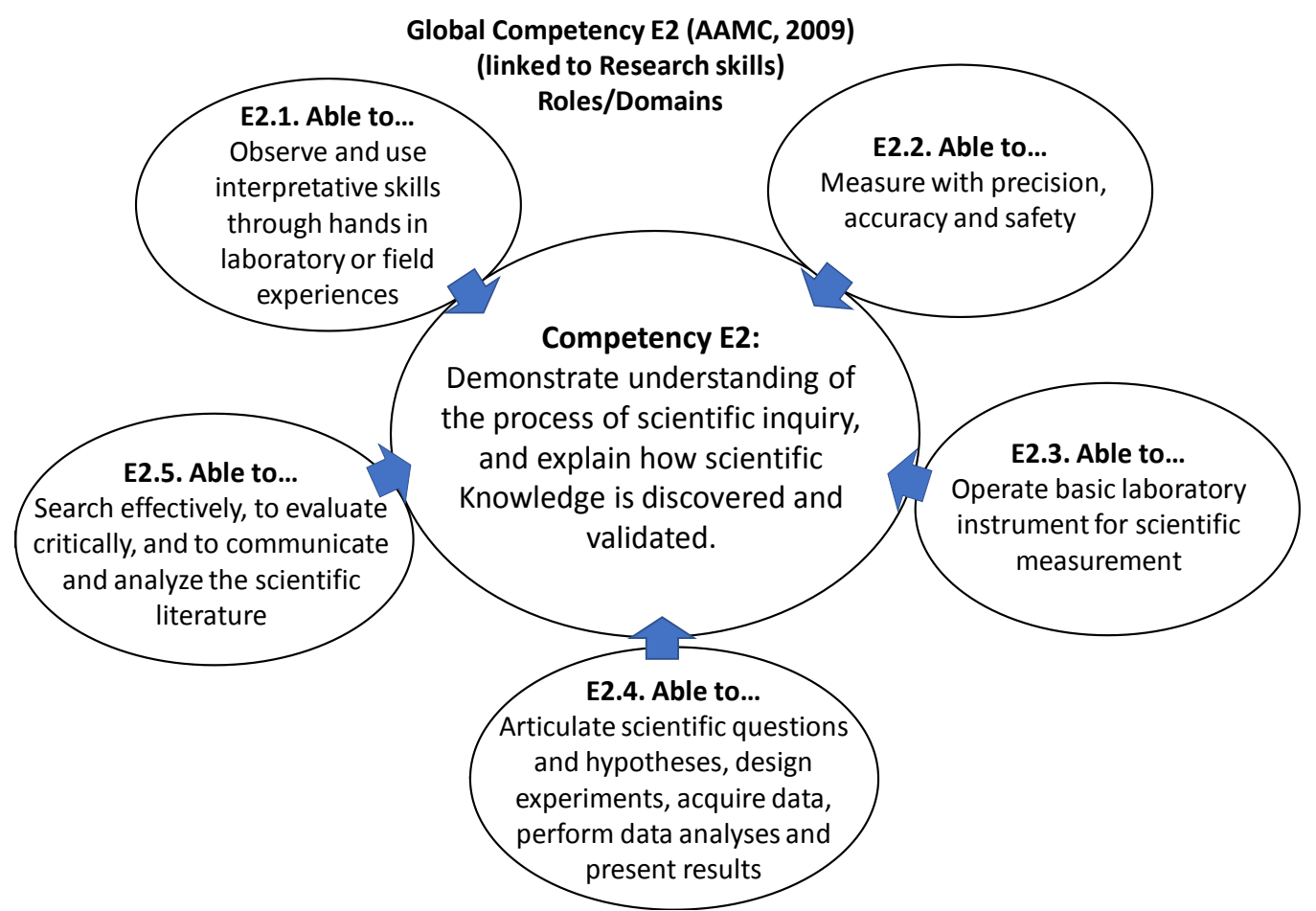

Figure 1:- Competency E2-Domains (Source: from information in AAMC, 2009).

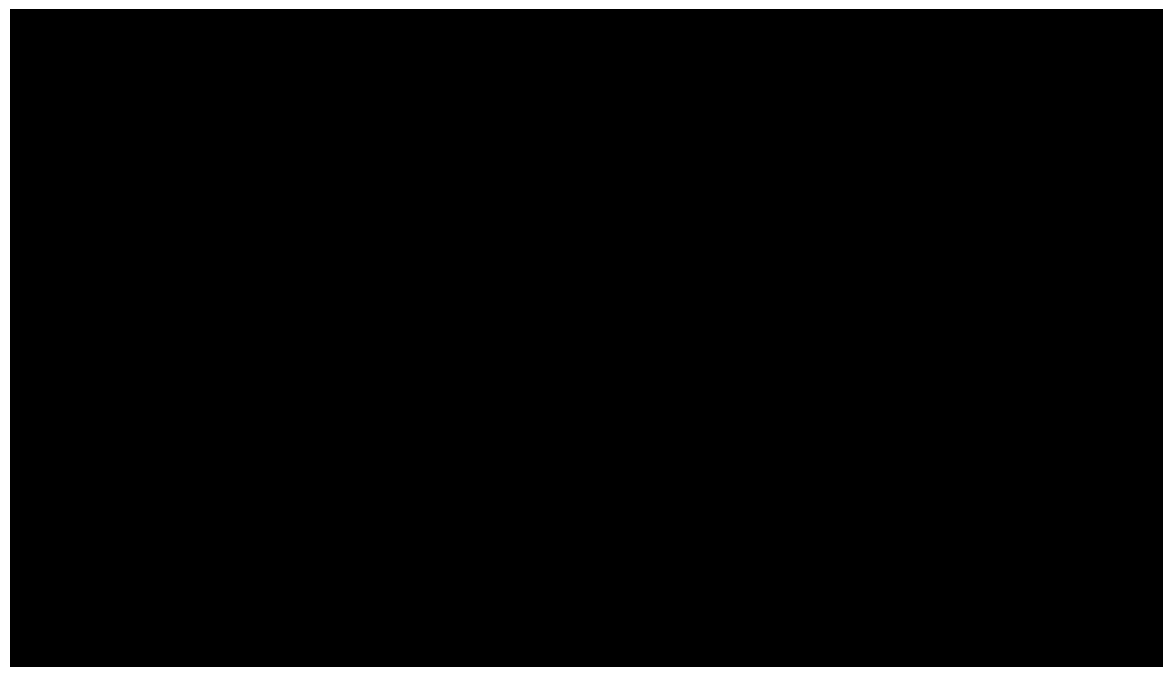

Figure 2:- EPAs-competency domains matrix.

Discrete tasks proposed like EPAs were based on some of the activities described by de AAMC (2009) to reach the learning objectives linked to Competency E2 and also inspired in the C.R.E.A.T.E. (Consider, Elucidate hypotheses, Analyse and interpret data, Think of the next Experiment) approach developed by Hoskins et al. (2011) to transforms the classroom into a virtual laboratory.

As it was mentioned before, EPAs development occurs at a workplace, the context in which most of the professional learning occurs (Ashton, 2004), connecting what trainees learn at the classroom and what they can apply once placed in real work (learning in situ). Taking this definition into account, a workplace in researcher's cases are different environments that include mainly Universities Departments, Hospitals laboratories, Research Centers and/or Research Enterprises Departments, were authentic activities and social interaction to learning take place (Collin, 2006). 
These examples are the following:

1. EPA1: Find relevant literature on a topic and be able to summarize and present the current state of knowledge (write an article of revision or prepare a manuscript for a grant apply as examples).

2. EPA2: Develop a small laboratory assay following a protocol (prepare an agarose gel, prepare different culture medium, or prepare different solutions and dilutions as examples).

3. EPA3: Use and/or calibrate properly basic laboratory instrumentation (balance, spectrophotometer, or optic microscope as examples).

4. EPA4: Analyse and infer conclusions based on measurements made during laboratory assays (bacteria growth, enzymatic activity or antibiotic production as examples).

5. EPA5: Design an experiment based in different papers information (conditions of microorganism growth, optimisation of a microorganism metabolite production or optimisation of an enzymatic reaction as examples).

6. EPA6: Write a potential research project (perhaps a small internal research group project or maybe a bigger one, like an interuniversity project; depending on different contexts).

\section{Complete EPA model:}

As Cameron et al. (2015) point out, while Universities have begun to recognize the importance of scientific writing ability, scientific writing study is not a standard part of the research training curriculum in most of health/life science degrees. Fisher and Zigmon (2001) also argued that is common for students to enter and exit graduate for medical school with no formal training in scientific writing. Nevertheless, research trainees are expected to write in a professional academic register (Snow 2010). Thus, accordingly with the studies developed by Cameron et al. (2015) the develop of scientific communication skills is critical disregarded component of career preparation for trainees.

With this background exposed, between the EPAs proposed, EPA1 was selected to develop in depth like a model or example of EPA to competency-based education in the context of the basic sciences to develop competency E2 of the trainees (table 1). EPA1: Find relevant literature on a topic and be able to summarize and present the current state of knowledge (in particular: to write an article of revision).

The information and details included in the EPA example developed, follow the same scheme proposed by Chen et al. (2016) in the example of EPA to entry into clerkship.

Table 1:- Example of an early EPA (EPA1) in undergraduate health/life science to develop competency E2 (AAMC, 2009).

\begin{tabular}{|l|l|}
\hline \multicolumn{1}{|c|}{ EPA title } & Write an article of revision \\
\hline 2. Specifications and limitations & Specifications \\
& The topic should be included in a supervising professor's real \\
& research project or a research line to be develop in the future. \\
& The trainee will be integrated in the research group to work with and \\
exchange opinions and thoughts about the study subject (social & interaction). \\
& Limitations \\
& The work must be developed in a period conditioned to the specific \\
& curriculum program. \\
\hline 3. Specific Knowledge, skills, and attitudes & Knowledge: \\
needed to execute the EPA well (curriculum & - able to properly selection of the topic (a little background and \\
reference depends on the specific program & general Knowledge about the project or research line to be integrate \\
follow by the student) & in) \\
& Skills: \\
& - able to develop a manageable working plan \\
& - able to search properly bibliography \\
& - able to select correct documentary sources \\
& - able to access most important databases \\
& - able to analyze properly the information selected \\
& - able to synthesize information \\
& - able to put the ideas in order and write the article \\
& Attitudes: \\
\hline
\end{tabular}




\begin{tabular}{|c|c|}
\hline & - able to enrich information with professional personal exchanges \\
\hline $\begin{array}{l}\text { 4a. Link to supervising professor/senior } \\
\text { researcher and research competencies }\end{array}$ & $\begin{array}{l}\text { - Linked to specific objectives of the supervising professor's } \\
\text { research project or research line. } \\
\text { - Linked to Competency E2 (see Figure 1): Demonstrate } \\
\text { understanding of the process of scientific inquiry and explain how } \\
\text { scientific Knowledge is discovered and validated. } \\
\text { - Specifically linked to E2.4 (see Figure 1): Find relevant literature } \\
\text { on a topic and be able to summarize and present the current state of } \\
\text { knowledge. }\end{array}$ \\
\hline $\begin{array}{l}\text { 4b. Link to graduation competencies and } \\
\text { milestones most applicable to this EPA }\end{array}$ & $\begin{array}{l}\text { Linked to general/transversal/global basic science competences (in } \\
\text { Educational Programs of Biology, Biochemistry, Physiology, } \\
\text { Cytology...) }\end{array}$ \\
\hline $\begin{array}{l}\text { 4c. Link to EPAs from professional } \\
\text { organizations }\end{array}$ & There are no EPAs described for related professional organizations. \\
\hline 5. Information sources to gauge progress & $\begin{array}{l}\text { Trainee should fill two electronic portfolios during de activity } \\
\text { progress: } \\
1^{\circ} \text {. At the end of the documental sources' selection (portfolio details: } \\
\text { data bases used, number and type of documentary sources consulted, } \\
\text { number and type of documentary sources selected). } \\
2^{\circ} \text {. Just before to write the article (portfolio details: outline of the } \\
\text { article) }\end{array}$ \\
\hline 6. Method for formal entrustment decision & $\begin{array}{l}\text { According to the levels of supervision determined by Ten Cate et al. } \\
\text { (2015), level } 4 \text { is proposed: permission to act under distant } \\
\text { supervision not directly available. }\end{array}$ \\
\hline $\begin{array}{l}\text { 7. Conditions and implications of } \\
\text { entrustment for the student }\end{array}$ & $\begin{array}{l}\text { Trainee will be allowed without supervision to: } \\
\text { 1. search information in data bases } \\
\text { 2. analyze and do the selection of the main documental sources } \\
\text { 3. put the ideas in order and write the outline of the article (without } \\
\text { supervision but at this point professional exchange of opinions and } \\
\text { reflections will be desired) }\end{array}$ \\
\hline
\end{tabular}

\section{Final consideration:}

As the new educational paradigm imposes (both in America and Europe) and with the main goal of ending the historical rift between science researchers and science educators and in the way to learn science doing science, both, scientifics and educators may work together to find out new methodological approaches to develop an authentic competence-based curriculum of health/live sciences undergraduate students. Ideally, an EPA briefly and meaningfully describes the main professional activities and is sufficiently general to be applicable in different contexts; EPA-concept should help to narrow a specialism down to independent professional activities without losing the holistic view of the profession (Van Loon et al., 2014). Focusing the interest especially in the enhance of the research abilities of the students, this work proposes to transfer de EPA-concept from de clinical sciences to the basic science to have a standard guideline for research mentors to follow and offer like an example, a EPAcompetencies matrix and complete EPA-model. The questions that would remain unresolved would be, when should a student -who wishes to be a researcher- be evaluated through these EPAs? How would an EPA-based curriculum for researchers be constructed? The proposal opens a line to discuss the implications and challenges that this concept-transfer offers to the improvement of the science research competences.

\section{References:-}

1. American Association for the Advancements of Science -AAAS- (2009). Celebrating our planet and the promise of science and technology. AAAS Annual Report 2009. Washington, USA: AAAS. Retrieved from: https://www.aaas.org/sites/default/files/AnnualReports/2009/aaas_ann_rpt_2009.pdf

2. AAMC/HHMI Committee Defines Scientific Competencies for Future Physicians (2009). Report of the AAMC-HHMI Committee. Washington, USA: Association of American Medical Colleges. Retrieved from: https://www.hhmi.org/sites/default/files/Programs/aamc-hhmi-2009-report.pdf

3. Achtenhagen, F. (2005). Competence and their development: cognition, motivation, metacognition, in: W. J. Nijhof\& L. F. M. Nieuwenhuis (Eds), The learning potential of the workplace, Twente: University of Twente. 
4. Ashton, (2004). The impact of organisational structure and practices on learning in the workplace. International Journal of Training \& Development 8(1), 43-53.

5. Bloom, B., Englehart, M., Furst, E., Hill, W. \& Krathwohl, D. (1956). Taxonomy of educational objectives: The classification of educational goals. Handbook I: Cognitive Domain. New York, Toronto: Longmans, Green.

6. Cameron, C., Lee, H. Y., Anderson, C., Byars-Winston, A., Baldwin, C. D. \& Chang, S. (2015). The Role of Scientific Communication Skills in Trainees' Intention to Pursue Biomedical Research Careers: A Social Cognitive Analysis. CBE-Life Science Education, 14, 1-12.

7. Campbell., A. \& Sommers Luchs, K. (1997). Core Competency-Based Strategy. London, England: International Thomson Business Press.

8. Caverzagie, K. J., Cooney, T. G., Hemmer, P. A. \& Berkowitz, L. (2015). The Development of Entrustable Professional Activities for Internal Medicine Residency Training: A Report from the Education Redesign Committee of the Alliance for Academic Internal Medicine. Academic Medicine, 90(4), 479-484.

9. Chen, H., McNamara, M., Teherani, A., ten Cate, O., \&O'Sullivan, P. (2016). Developing entrustable professional activities for entry into clerkships. Academic Medicine, 91(2), 247-255.

10. Chen, H., van cien Broek, W.E. \& ten Cate, O. (2015). The case for use of entrustable professional activities in unclergracluate medical eclucation. Academic Medicine 90(4), 431-436.

11. Collin, K. (2006). Connecting work and learning: Design engineers' learning at work. Journal of Workplace Learning, 18(7/8), 403-413.

12. Epstein, R. M \& Hundert, E. M. (2002). Defining and assessing professional competence. JAMA, 287(2), 226235.

13. Eraut, M. (1994). Developing Professional Knowledge and Competence. London, England: The Falmer press.

14. Fisher, B. A. \&Zigmon, J. Z. (2001). Promoting responsible conduct in research through "survival skills" workshops: Some mentoring is best done in a crowd. Science and Engineering Ethics, 7(4), 563-587.

15. Frank (2005). The CanMEDS 2005 Physician Competency Framework. Better standards. Better physicians. Better care. Ottawa, Canada: The Royal College of Physicians and Surgeons of Canada. Retrieved from: http://www.ub.edu/medicina_unitateducaciomedica/documentos/CanMeds.pdf

16. Gilhooly, J., Schumacher, D. J., West, D. C. \& Jones, M. D. (2014). The Promise and Challenge of Entrustable Professional Activities. Pediatrics, 133(2), 578-579.

17. Gonczi., A., Curtain, R., Hager, P., Hallard, A. \& Harrison, J. (1995). Key competencies in on-the-job training: a report. Broadway, New South Wales: University of Technology, Sydney.

18. Hardem, R. M. (2002). Learning outcomes and instructional objectives: is there a difference? Medical Teacher, 24(2), 151-155.

19. Haines, S. T., Pittenger, A. L., Gleason, B. L., Medina, M. S. \& Neely, S. (2018). Validation of the entrustable professional activities for new pharmacy graduates. American Journal of Health-System Pharmacy, 75(23), 1922-1929. Retrived from: https://doi.org/10.2146/ajhp170815

20. Hoskins, S. G., Lopatto, D. \& Stevens, L. M. (2011). The C.R.E.A.T.E. Approach to Primary Literature Shifts Undergraduates' Self-Assessed Ability to Read and Analyze Journal Articles, Attitudes about Science, and Epistemological Beliefs. CBE-Life Sciences Education, 10, 368-378.

21. Korthagen, F. A. J. (2004). In search of the essence of a good teacher: towards a more holistic approach in teacher education. Teaching and Teacher Education, 20, 77-97

22. McClelland, D. C. (1973). Testing for Competence Rather Than for "Intelligence". American Physiologist. Retrieved from: https://www.therapiebreve.be/documents/mcclelland-1973.pdf

23. McCloskey, C. B., Domen, R. D. \& Conran, R. M. (2017). Entrustable Professional Activities for Pathology: Recom-mendations From the College of American Pathologists Graduate Medical Education Committee. Academic Pathology. Retrived from: https://doi.org/10.1177/2374289517714283

24. McNamara, D. (1992). The reform of teacher education in England and Wales: teacher competence; panacea or rhetoric? Journal of Education for Teaching, 18(3), 273-286.

25. Mitrani, A., Dalziel, M. \&Fitt, D. (1992). Competency Based Human Resource Management. London, England: Kogan Page.

26. Mulder, M., Weigel, T. \& Collins, K. (2008). El concepto de competencia en el desarrollo de la educación y formación profesional en algunos Estados miembros de la UE: un análisis crítico. Profesorado. Revista de Currículum y Formación de Profesorado, 12(3), 1-25.

27. Mulder, M., Weigel, T. \& Collins, K. (2007). The concept of competence in the development of vocational education and training in selected EU member states: a critical analysis. Journal of Vocational Education \& Training, 59(1), 67-88. 
28. Nadler, D. A. \& Tushman, M. (1999). The Organization of the Future: Strategic Imperatives and Core Competencies for the 21st Century. Organizational Dynamics, 27(1), 45. Retrieved from: https://go.galegroup.com/ps/i.do?p=AONE\&sw=w\&u=googlescholar\&v=2.1\&it=r\&id=GALE\%7CA55144553 $\&$ sid $=$ classroomWidget\&asid $=66 \mathrm{e} 4 \mathrm{f} 2 \mathrm{c} 3$

29. Norris, N. (1991). The Trouble with Competence. Cambridge Journal of Education, 21(3), 331-341.

30. OECD, DeSeCo\&Rychen (2003). Definition and selection of competencies. Theoretical and conceptual foundations (DeSeCo). Summary of the final report 'Key competencies for a successful life and a wellfunctioning society'. Retrieved from: http://www.portal-stat.admin.ch/deseco/deseco_finalreport_summary.pdf

31. Pfund, C., Spencer, K. C., Asquith, P., House, S. C., Miller, S. \&Sorkness, C. A. (2015). Training Mentors of Clinical and Translational Research Scholars: A Randomized Controlled Trial. CBE-Life Sciences Education, $14,1-12$.

32. Ries, A., Wingard, D., Morgan, C., Farrell, E., Letter, S. \& Reznik, V. (2009). Retention of junior faculty in academic medicine at the University of California, San Diego. Academic Mededecin, 84, 37-41.

33. Sadler, T. D. \&Mckinney, L. (2010). Scientific Research for Undergraduate Students: A Review of the Literature. Journal of College Science Teaching, 39(5), 43-49.

34. Scheele, F., Caccia, N., Van Luijk, S., Van Loon, K., \& De Rooyen, C. (2013). BOEG - Better Education for Obstetrics and Gynaecology. A national competency-based curriculum for obstetrics \&gynaecology v.1. Utrecht, the Netherlands: Netherlands Association for Gynaecology and Obstetrics.

35. Schultz, K., Griffiths, J. \& Lacasse, M. (2015). The application of entrustable professional activities to inform competency decisions in a family medicine residency program. Academic Medicine, 90, 888-897.

36. Shumway, N. M., Dacus, J., Lathrop, K., Hernandez, E., Miller, M. \&Karnad, A. (2015). Use of milestones and development of entrustable professional activities in 2 hematology/oncology training programs. Journal of Graduate Medical Education, 7(1), 101-104.

37. Snow, C. E. (2010). Academic Language and the Challenge of Reading for Learning About Science. Science, $328,450-452$.

38. Solorzano, D. (1998). Critical race theory, race and gender microaggressions, and the experience of Chicana and Chicano scholars. International Journal of Qualitative Studies in Education, 11, 121-136.

39. Spencer, L. \& Spencer, S. (1993). Competence at work: a model for superior performance. New York, USA: Wiley.

40. Struyven, K. \& De Meyst, M. (2010). Competence-based teacher education: Illusion or reality? An assessment of the implementation status in Flanders from teachers' and students' points of view. Teaching and teacher Education, 26(8), 1495-1510.

41. Ten Cate, O. (2020). An Updated Primer on Entrustable Professional Activities (EPAs). Revista Brasileira de Educação Médica, 43(1). Retrievedfrom: http://dx.doi.org/10.1590/1981-5271v43suplemento1-20190238.ing

42. Ten Cate, O., Chen, H. C., Hoff, R. G., Peters, H., Bok, H. \& van der Schaaf, M. (2015). Curriculum development for the workplace using Entrustable Professional Activities (EPAs): AMEE Guide No. 99. Medical Teacher, 37(11), 983-1002.

43. Van Dongen, T. (2003). Management of competences. So what? A humanfriendly approach. Zaltbommel, the Netherlands: Schouten \&Nelissen.

44. Van Loon, K. A., Driessen, E. W., Teunissen, P. W. \& Scheele, F. (2014) Experiences with EPAs, potential benefits and pitfalls. Medical Teacher, 36(8), 698-702.

45. Vos Chair, S. S., Brown, M. M., Cardello, E. A., Dintzner, M. R., MacKinnon, G. E., Maroyka, E. M., Mbi, P., Park, S. K., Weaver, K. K., Zeeman, J. M., Bradley-Baker, L. R. \& Plaza, C. M. (2018). The Report of the 2017-2018 Pro-fessional Affairs Standing Com-mittee: The Development of the Preceptor Self-Assessment Tool for Entrustable Professional Ac-tivities for New Graduates. American Journal of Pharmaceutical Education September, 82(7), 7162. Retrieved from: https://doi.org/10.5688/ajpe7162

46. Weinert, F. E. (2001). Concept of competence: a conceptual clarification. In D.S.Rychen., \&L.H.Salganik (Eds.): Defining and selecting key competencies (pp. 45-66). Göttingen, Germany: Hogrefe.

47. Wesselink, R., Lans, T., Mulder, M., Biemans, H.J.A. (2003). In: Proceedings of the program presented by the research network on vocational education and training (VETNET) at the European Conference on Educational Research (ECER). Hamburg, Germany.

48. Wesselink, R., Biemans, H. J. A., van den Elsen, E. \& Mulder, M. (2005). Conceptual framework for competence-based VET in the Netherlands. Retrived from: http://www.vetresearch.net/ecer_2005/fri09/session7a/P20050000789/

49. Winterton, J., Delamare Le-Deist, F. \&Stringfellow, E. (2005). Typology of knowledge, skills and competences: clarification of the concept and prototype, Thessaloniki: Cedefop. 